\title{
Fibrodysplasia Ossificans Progressiva: A don't Touch Syndrome
}

\author{
Mahmut Nedim Aytekin*1, Buğra Alpan², Ercan Bal ${ }^{1}$, Maimaiti Mairedanjiang ${ }^{1}$ and Harzem Özger ${ }^{2}$ \\ ${ }^{1}$ Department of Orthopedics and Traumatology, Medicine Faculty, Ankara Yildirim Beyazit University, Turkey \\ ${ }^{2}$ Istanbul Orthopedic Oncology Group, Turkey
}

*Corresponding author : Assoc Prof Mahmut Nedim Aytekin, MD, Department of Orthopedics and Traumatology, Medicine Faculty, Ankara Yildirim Beyazit University, Turkey.

Received Date: April 09, 2019

Published Date: April 22, 2019

\begin{abstract}
Fibrodysplasia ossificans progressiva (FOP) is a rare genetic disease that is characterized by the formation of heterotopic bone tissues in soft tissues, such as skeletal muscle, ligament, and tendon. The prevalence is one in two million people. During childhood, it may be asymptomatic but in later life, progressive stiffness of major joints renders movement of the individual impossible. Currently, there is no effective treatment for this debilitating disease. Here, we present a case of 32 years old male with clinical and radiological features of fibrodysplasia ossificans progressiva.
\end{abstract}

Keywords: Fibrodysplasia ossificans progressiva; Heterotopic ossification

\section{Introduction}

Fibrodysplasia Ossificans Progressiva (Munchmeyer's disease, stoneman's disease, Myositis Ossificans Progressiva) first described by Guy Patin in 1692 [1,2]. It is a rare progressively disabling disease characterized by formation of heterotopic bone tissues in soft tissues, such as skeletal muscle, ligament, and tendon that gradually encases the original skeleton resulting in restriction of movement and eventual immobility and mortality from cardiorespiratory complications around the fourth decade of life $[1,3]$. It is extremely rare with an incidence of one in two million individuals occurring without bias to gender, race or ethnicity [4]. It is an autosomal dominant disorder with most patients having a spontaneous new mutation of a bone morphogenic protein type 1 receptor (ACVR1) which results in activation of osteogenesis in ectopic sites without ligand binding [5,6]. Familial cases have also been reported [7].

Minor trauma such as intramuscular immunizations, mandibular blocks for dental work, muscle fatigue, blunt muscle trauma from bumps, bruises, falls, or influenza-like viral illnesses can trigger painful new flare-ups of FOP leading to progressive heterotopic ossification [8]. Surgical removal of heterotopic bone provokes explosive and painful new bone growth. The correct diagnosis of FOP can be made clinically even before radiographic evidence of heterotopic ossification is seen, if soft tissues lesions are associated with symmetrical malformations of the great toes.
Definitive genetic testing of FOP is now available and can confirm a diagnosis of FOP prior to the appearance of heterotopic ossification. Clinical management of FOP remains symptomatic [8].

\section{Case Presentation}

A 32 years old male presented with pain on right knee and difficulty of walking. Clinical records reveal that at the age of about 12 , he was diagnosed with congenital disease. On the physical examination: we found that he has a stiff right knee which was at the position of 70 degree flexion without any motion. The range of motion of his left hip has been decreased. His endocrinologic and systemic screening was normal except his musculoskeletal system problems. He had an excisional biopsy operation from his right hip six months ago in a medical centre. The size of excisional material was $12 \times 4 \times 4 \mathrm{~cm}$ and pathology result was; 'sclerotic bone trabeculas + bone marrow tissues + environmental fibrous tissues'. This case has been consulted on Musculoskeletal Oncology Committee of Ankara and the decision of the committee was 'DON'T TOUCH'.

\section{Discussion}

Fibrodysplasia ossificans progressiva (FOP), a rare and disabling genetic condition characterized by progressive heterotopic ossification (HEO) [9]. Surgical interventions are risk for new trauma-induced HO formation and release of joint contracture is generally unsuccessful $[10,11]$. Even A biopsy is contraindicated 
due to risk of catastrophic explosive new bone formation. Spinal bracing is ineffective and surgical intervention is associated with numerous complications [10-12]. On this report, we could give a comment to this syndrome as 'Don't Touch Syndrome'.
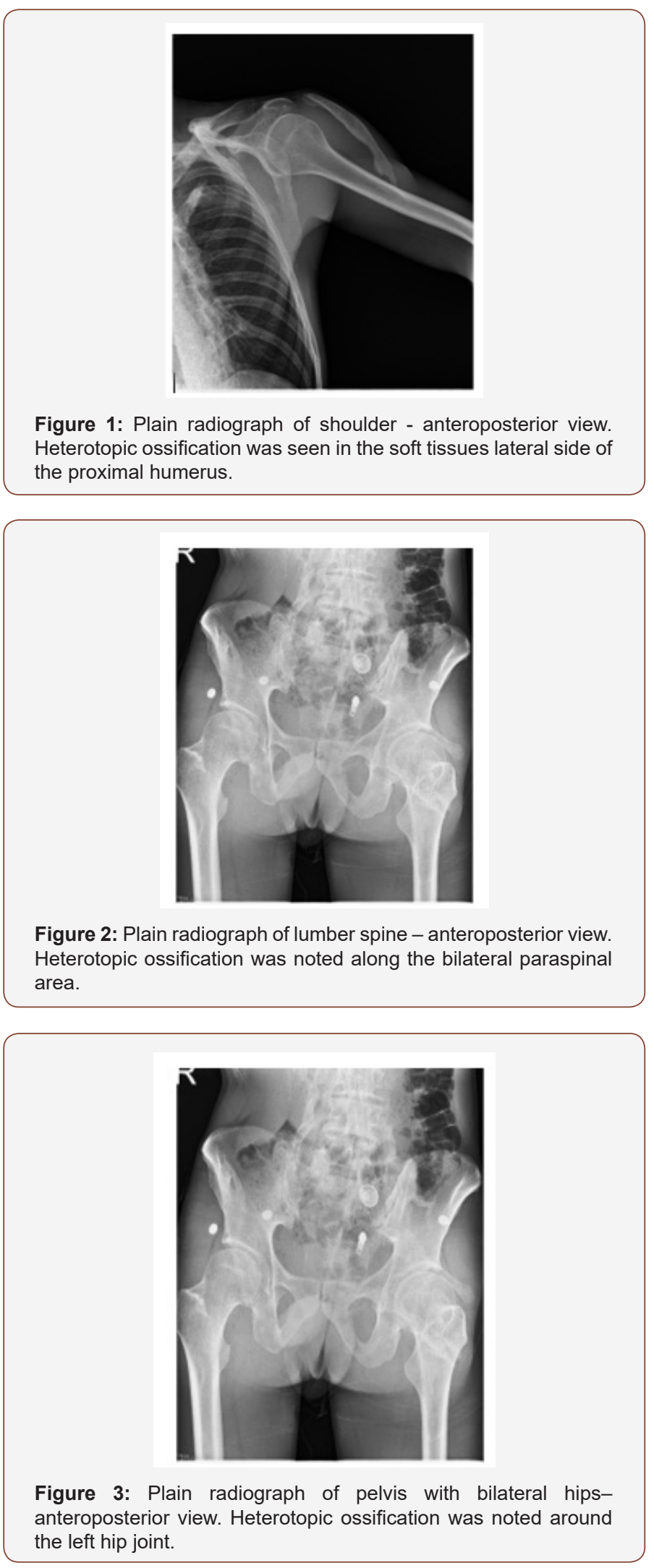

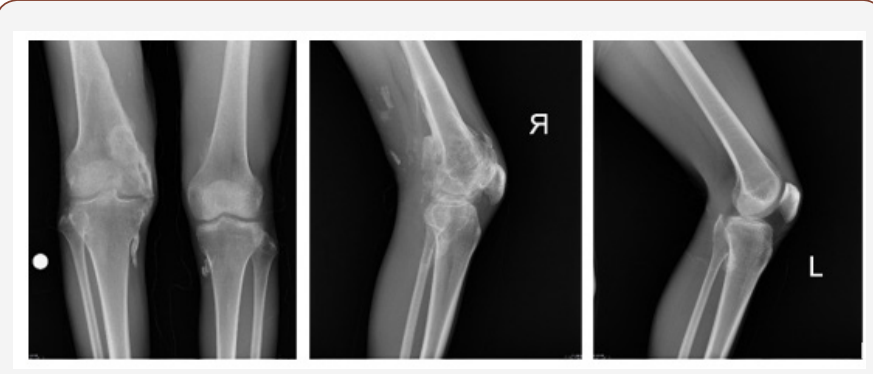

Figure 4: Plain radiograph of both knee- anteroposterior and lateral view. Heterotopic ossification was noted medial side of the right knee as well as bilateral proximal tibia.

\section{Acknowledgement}

None.

\section{Conflict of Interest}

No conflict of interest.

\section{References}

1. Illingworth RS (1971) Myositis Ossificans Progressiva (Munchmeyer's disease) A brief review with report of two cases treated with corticosteroids and observed for 16 years. Arch Dis Child 46(247): 264268.

2. Pignolo JS, Shore EM, Kaplan FS (2011) Fibrodysplasia Ossificans Progressiva: Clinical and genetic aspects. Orphanet J Rare Dis 6: 80.

3. Kaplan FS, Zasloff MA, Kitterman JA, Shore EM, Hong CC, et al. (2010) Early Mortality and Cardiorespiratory failure in patients with fibrodysplasia Ossificans progressive. J Bone Joint Surg Am 92(3): 686691.

4. Kaplan FS, Xu M, Glaser DL, Collins F, Connor M, et al. (2008) Early diagnosis of Fibrodysplasia Ossificans Progressiva. Pediatrics 121(5): el295-300.

5. Shore EM, Xu M, Feldman GJ, Fenstermacher DA, Cho TJ, et al. (2006) A recurrent mutation in the BMP type 1 receptor ACVR1 causes inherited and sporadic fibrodysplasia Ossificans progressiva. Nat Genet 38(5): 525-527.

6. Shore EM (2012) Fibrodysplasia Ossificans progressiva (FOP): A human genetic disorder of extraskeletal bone formation, or - How does one tissue become another? Wiley interdiscip Rev Dev Biol 1(1): 153-165.

7. Hampton I, Ofori Amanfo G (1998) A familial case of Fibrodysplasia Ossificans Progressiva (myositis ossificans progressive). Trop Doct 28(2): 108-109.

8. Kaplan FS, Le Merrer M, Glaser DL, Pignolo RJ, Goldsby RE, et al. (2008) Fibrodysplasia ossificans progressiva. Best Pract Res Clin Rheumatol 22(1): 191-205.

9. Pignolo RJ, Shore EM, Kaplan FS (2013) Fibrodysplasia ossificans progressiva: diagnosis, management, and therapeutic horizons. Pediatr Endocrinol Rev 10(Suppl 2): 437-448.

10. Shah PB, Zasloff MA, Drummond D, Kaplan FS (1994) Spinal deformity in patients who have fibrodysplasia ossificans progressiva. J Bone Joint Surg Am 76(10): 1442-1450.

11. Trigui M, Ayadi K, Zribi M, Triki Z, Keskes H (2011) Fibrodysplasia ossificans progressiva: diagnosis and surgical management. Acta Orthop Belg 77(2): 139-144.

12. Morales Piga A, Kaplan FS (2010) Osteochondral diseases and fibrodysplasia ossificans progressiva. Adv Exp Med Biol 686: 335-348. 